\title{
PENGARUH TERAPI PERILAKU (TEKNIK MODELLING DAN TOKEN EKONOMI) TERHADAP FREKUENSI ENURESIS PADA ANAK USIA PRASEKOLAH (4-6 TAHUN)
}

Abd Wahid, Program Studi Ners UNIJA Sumenep

e-mail: elwahid9@gmail.com

Sri Yunita Suraida Salat, Program Studi Kebidanan UNIJA Sumenep

e-mail: ita_shalat@yahoo.com

\section{ABSTRACT}

Enuresisis urinary problem sare often found in childhood and cause concern for patients and their families. The results of preliminary studies that have been carried outin Apri I2014, of 10 children aged 4-6 years who were in the village of Sejati Slabayan District of Camplong Sampang found that $60 \%$ of children aged4-6 years experience denuresis and $40 \%$ did not experience enuresis.

This study is an experimental pre-one group pretest-posttest design. Collecting data using pre and post observations. Data was taken on the majority of children who have enuresis of purposive sampling technique. The results were analyzed using descriptive and correlation parametric test paired $t$-test.

The frequency of enuresis in children before and after behavior therapy there are significant differences. Analysis of parametric tes twith a variable scale paired t-test shows that there is influence between behavior therapy (modeling techniques and token economy) to decrease the frequency of enuresis $(p=0.000)$.

To further research the authors suggest that continued follow-up study with some preparation sinclude a clearand practical education to the respondent, the procurement of more stringent environmental controls, manufacture of detector surinate more flexible, so that it can be better.

Keyword: Behavior Therapy, Modeling Techniques, Token Economy, Enuresis

Setiap orang mulai lahir sampai masa anak-anak tertentu pernah mengalami ngompol yang disebut enuresis. Enuresis merupakan masalah yang sering ditemukan pada masa kanak-kanak dan menimbulkan kekhawatiran bagi orang tua. Pada prevalensi enuresis pada anak usia 2 tahun $82 \%$, usia 3 tahun $49 \%$, dan usia 4 tahun sebanyak $36 \%$ dan anak 5 tahun sebesar 7\% (Kaplan dan Sadock, 2007).

Angka kejadian enuresis diberbagai negara bervariasi. Menurut Tridjaja (2005), survei di Jakarta pada murid sekolah dasar (laki-laki 2084 orang, perempuan 2120 orang) menyebutkan prevalensi enuresis pada anak laki-laki sekitar 2,83\% dan anak perempuan $2,97 \%$, dimana $82,4 \%$ diantaranya tergolong enuresis nokturnal dan 17,60 \% tergolong enuresis diurnal, 96,70\% bersifat primer dan hanya 3,30\% enuresis sekunder.

Terapi perilaku merupakan salah satu terapi untuk anak yang mengalami enuresis. Anak dibiasakan buang air kecil lebih sering dan terjadwal serta membiasakan buang air kecil setelah bangun tidur dan sebelum tidur. Hal ini memerlukan motivasi berkelanjutan serta dilakukan evaluasi setiap 6 bulan. Anak berusaha menjadi tidak enuresis dengan berusaha mengumpulkan poin-poin untuk ditukar dengan hadiah yang telah disepakati.
Sedangkan teknik modelling adalah teknik belajar dengan mengamati seseorang kemudian mencontohkan perilakunya. Tenik perilaku modelling ini memungkinkan seseorang mengubah perilakunya yang maladaptif menjadi adaptif dengan cara mencontoh seseorang yang dipercaya sebagai model atau teladan. Anak yang menderita enuresis bisa juga membutuhkan model yang bisa memotivasi dirinya untuk tidak ngompol lagi. Model tersebut bisa dari teman sebayanya, atau anggota keluarga yang lain

\section{RUMUSAN MASALAH}

Apakah ada pengaruh terapi perilaku (teknik modelling dan token ekonomi) terhadap enuresis pada anak usia pra sekolah (4-6 tahun) di Desa Sejati Kecamatan Camplong Kabupaten Sampang?

\section{Metode Penelitian}

Penelitian ini adalah penelitian pre eksperimental one-group pretest-postest design. Pada penelitian ini terdapat satu kelompok yang diberikan perlakuan yaitu terapi perilaku; teknik modelling dan token ekonomi terhadap frekuensi enuresis pada Anak Usia Prasekolah (4-6 Tahun). Populasinya adalah semua anak usia 4-6 tahun (prasekolah) yang 
mengalami enuresis di Desa Sejati Kecamatan Camplong Sampang, dengan jumlah 18 anak. Sampel Pada penelitian ini anak usia prasekolah yang mengalami enuresis di Desa Sejati Kecamatan Camplong Sampang. Sebanyak 17 orang.

Cara pengambilan sampel pada menelitian ini menggunakan non probability sampling: purposive sampling, yaitu suatu teknik pengambilan besar sampel dengan cara memilih diantara populasi sesuai kehendak peneliti (waktu, biaya dan tempat), sehingga sampel mewakili karakteristik populasi yang telah dikenal sebelumnya, dengan kriteria sebagai berikut: Anak usia pra sekolah (4-6 tahun), Anak tidak memakai diapers/popok, Kooperatif dan tidak mengalami gangguan pertumbuhan dan perkembangan, Tidak sakit. Pengumpulan data-data yang diperlukan, menggunakan instrument penelitian pada variabel bebas adalah wawancara sesuai dengan SOP, sedangkan pada variabel terikatnya dengan menggunakan lembar observasi.

\section{HASIL PENELITIAN}

\section{Data Umum}

1. Frekuensi responden menurut jenis kelamin

\begin{tabular}{cccc}
\hline No & Jenis Kelamin & $\mathrm{F}$ & $(\%)$ \\
\hline 1. & Laki-laki & 13 & 76,47 \\
2. & Perempuan & 4 & 23,53 \\
\hline & Total & 17 & 100
\end{tabular}

Berdasarkan tabel 1 didapatkan dari 17 responden hampir seluruhnya $(76,47 \%)$ berjenis kelamin laki-laki

2. Frekuensi responden menurut umur

\begin{tabular}{cccc}
\hline No & Usia & $\mathrm{F}$ & $(\%)$ \\
\hline 1. & 4 Tahun & 4 & 23,53 \\
2. & 5 Tahun & 5 & 29,41 \\
3. & 6 Tahun & 8 & 47,06 \\
\hline & Total & 17 & 100 \\
\hline
\end{tabular}

Berdasarkan tabel 2 dari 17 responden, hampir setengahnya $(47,06 \%)$ berumur 6 tahun

\section{Data Khusus}

Tabel 3 Kejadian Frekuensi Enuresis sebelum dan setelah Terapi Perilaku (Token ekonomi dan Teknik Modelling)

\begin{tabular}{ccc}
\hline No & Sebelum & Setelah \\
\hline 1 & 3 & 1 \\
2 & 3 & 1 \\
3 & 2 & 1 \\
4 & 1 & 0
\end{tabular}

\begin{tabular}{ccc}
5 & 2 & 1 \\
6 & 2 & 1 \\
7 & 3 & 1 \\
8 & 4 & 2 \\
9 & 2 & 1 \\
10 & 2 & 0 \\
11 & 1 & 0 \\
12 & 4 & 2 \\
13 & 3 & 1 \\
14 & 3 & 1 \\
15 & 3 & 0 \\
16 & 3 & 0 \\
17 & 3 & 0 \\
\hline Rata-rata & 3 & 1 \\
\hline P value & & 0.000 \\
\hline
\end{tabular}

Berdasarkan tabel 3 didapatkan data dari 17 responden, frekuensi enuresis yang sebelum mendapat terapi perilaku (token ekonomi dan teknik modelling) rata-rata 3 kali sehari, setelah mendapatkan terapi perilaku (token ekonomi dan teknik modelling) frekuensi enuresisnya menurun menjadi rata-rata 1 kali dalam sehari. Berdasarkan uji statistik pengaruh terapi perilaku (token ekonomi dan teknik modelling) terhadap kejadian enuresis dengan menggunakan uji parametrik paired ttest didapakan nilai $p$-value sebesar 0,000 $(<0,05)$ adalah hipotesis nol ditolak dan hipotesis satu diterima. Artinya terdapat pengaruh terapi perilaku (token ekonomi dan teknik modelling) terhadap kejadian enuresis pada anak usia 4-6 tahun di Desa Sejati Kecamatan Camplong Sampang.

\section{Pembahasan}

\section{Frekuensi enuresis sebelum terapi perilaku (token ekonomi dan teknik modelling.}

Berdasarkan hasil penelitian didapatkan data dari 17 responden, frekuensi enuresis sebelum terapi perilaku (token ekonomi dan teknik modelling) ada 8 responden yang frekuensi enuresisnya tinggi atau rata-rata 3 kali dalam sehari.

Enuresis adalah buang air kecil yang terjadi diluar kebiasaan normal yang sebenarnya pengendalian kandung kemih sudah tercapai. Enuresis ada yang terjadi di malam hari (sleep wetting / bedwetting) dan siang hari (awake wetting) (Evans J, 2003). Salah faktor yang menjadi penyebab enuresis adalah jenis kelamin. Enuresis di malam hari sering terjadi pada anak laki-laki, sedangkan diurnal enuresis sering terjadi pada anak 
perempuan. Enuresis nokturnal adalah buang air kecil yang tidak disadari ketika tidur, tanpa terdapat kelainan pada sistem saluran kemih, dimana anak tidak mampu bangun walau terdapat peningkatan tekanan dan volume kandung kemihnya (Noer, 2006).

Pada penelitian ini enuresis banyak terjadi pada laki-laki disebabkan beberapa hal misalnya kandung kemih yang kecil dan tidur anak yang sangat dalam sehingga anak tidak terbangun pada saat kandung kemih sudah sangat penuh. Orang tua sering menganggap anak laki-laki adalah anak yang bertanggung jawab. Orang tua sering menerapkan asuhannya dengan cara-cara yang keras dengan lebih menekankan kepada pemberian hukuman (hegative reinforcement) daripada pemberian pujian. Situasi inilah yang kadang memaksa anak menjadi stress sehingga anak menjadi suka ngompol dalam tidurnya

\section{Frekuensi enuresis setelah terapi perilaku (token ekonomi dan teknik modelling).}

Frekuensi enuresis pada 17 anak usia 4-6 tahun sebelum dilakukan terapi perilaku (token ekonomi dan teknik modelling) rata-rata frekuensi enuresisinya 3 kali dalam sehari dan setelah dilakukan terapi perilaku (token ekonomi dan teknik modelling) frekuensi enuresisnya mengalami penurunan dengan rata-rata 1 kali dalam sehari.

Terapi perilaku (behavioral therapy) Token ekonomi adalah satu bentuk mengubah perilaku yang tidak disukai menjadi perilaku yang disukai dengan menggunakan token atau koin (Ayllon, 2009). Sedangkan teknik modelling merupakan metode mengubah perilaku dengan mengamati seorang model, meniru dan akan berhasil mengubah perilaku yang. Individu akan belajar pada model-model yang telah ditetapkan dan menerima hadiah setelah mempertahankan berkurangnya frekuensi ngompolnya dan sebaliknya akan mendapat pengurangan hadiah jika masih tetap ngompol. Anak segera ke kamar mandi bila ingin kencing dan mereka dapat menahan keinginan kencing dalam beberapa waktu, terutama bila sedang bermain.

\section{Pengaruh Terapi Perilaku (Token ekonomi dan Teknik Modelling) terhadap Frekuensi Enuresis}

Berdasarkan uji statistik pengaruh terapi perilaku (token ekonomi dan teknik modelling) terhadap kejadian enuresis dengan menggunakan paired $t$ test didapakan nilai $p$ value $0,008 \quad(<0,05)$ adalah hipotesis satu diterima. Hal ini berarti terdapat Pengaruh Terapi perilaku (token ekonomi dan teknik modelling) terhadap kejadian enuresis pada anak usia 4-6 tahun di Desa Sejati Kecamatan Camplong Sampang.

Perubahan perilaku yang didapat dari pengalaman disebut belajar. Perubahan tersebut bisa dilihat dari sikap dan nilai. Hasil penelitian menunjukkan bahwa terapi perilaku dengan metode token ekonomi dan teknik modelling memberikan perubahan perkembangan pada diri anak, dengan penerapan terapi perilaku melalui token ekonomi dan teknik modelling frekuensi enuresis pada anak semakin berkurang. Teknik perilaku yang digunakan dalam pengubahan perilaku manusia berdasarkan pendekatan behaviorism adalah seperti teknik ekonomi token (token economy technique) dan teknik modelling (modelling technique). Token ekonomi adalah satu bentuk mengubah perilaku yang tidak disukai menjadi perilaku yang disukai dengan menggunakan token atau koin (Ayllon, 2009).

Sedangkan teknik modelling adalah strategi modifikasi perilaku melalui pengamatan perilaku terhadap model. Laraia (2009), menjelaskan teknik modelling merupakan pembentukan perilaku baru untuk meningkatkan keterampilan sehingga meminimalkan perilaku yang tidak sesuai. Pada penelitian ini sebagian besar responden mengalami penurunan frekuensi enuresis disebabkan oleh peran aktif dari orang tua (ibu) dalam memotivasi anak untuk tetap kering dan bekerjasama dengan anak untuk mencapai tujuan tersebut. Dengan token ekonomi orang tua (ibu) bekerjasama dengan anak untuk mengumpulkan poin-poin apabila anak tetap kering setiap harinya. Apabila anak berhasil tidak ngompo di pagi dan siang hari anak diberi poin masing-masing 10 poin, sedangkan apabila berhasil tidak ngompol dimalam hari anak diberi poin lebih besar yaitu 25 poin. Setiap anak berhasil mengumpulkan poin 50 anak diberi hadiah untuk anak perempuan diberi hadiah boneka dan anak laki-laki diberi hadiah mobil-mobilan. Demikian seterusnya.

Selain itu anak memiliki figur/contoh yang bisa menjadi teladan untuk tetap kering. Pada penelitian ini terdapat beberapa anak yang memiliki figur teman sebaya. Seperti pada anak usia 5 tahun terdapat 2 anak dan pada anak usia 6 tahun terdapat 4 anak yang memiliki figur teman sebaya sebagai model untuk tetap mempertahankan "keringnya". 
Orang tua terlebih dahulu bekerjasama dan memotivasi teman figurnya untuk mengajak dan mengajari subjek ketika mau buang air kecil atau buar air besar seperti memberi tahu, membuka celana sendiri dan pergi ke kamar mandi serta memberi tahu setelah selesai buang air. Pada penelitian ini letak keberhasilan dari terapi perilaku tersebut berasal dari kerjasama yang baik dan teratur dari masingmasing model dan motivasi anak. Model yang dipih pada penelitian ini adalah teman bermain dan anggota keluarga sendiri seperti saudara kandung (kakak), orang tua laki-laki dan orang tua perempuan. Setiap model berhasil membujuk responden untuk mengikuti polanya serta mengajari responden toilet training pada anak setiap ada keinginan untuk buang air.

\section{KESIMPULAN}

Kesimpulan tentang pengaruh terapi perilaku (token ekonomi dan teknik modelling) terhadap penurunan frekuensi enuresis pada anak usia 4-6 tahun (pra sekolah) adalah:

1. Frekuensi enuresis sebelum melakukan terapi perilaku (teknik modelling dan token ekonomi). Rata-rata frekuensi enuresis 3 kali dalam sehari.

2. Terdapat penurunan frekuensi enuresis setelah melakukan terapi perilaku (teknik modelling dan token ekonomi). Rata-rata frekuensi enuresis 1 kali dalam sehari.

3. Ada pengaruh terapi perilaku (teknik modelling dan token ekonomi) terhadap frekuensi enuresis

\section{SARAN}

Penelitian ini sebaiknya menggunakan variabel berbeda sehingga bisa mencapai frekuensi enuresisnya pada anak lebih baik.

1. Bagi peneliti

Peneliti yang akan datang, diharapkan melakukan-persiapan diantaranya besar sampel yang lebih besar, kontrol lingkungan, detektor kencing yang fleksibel, sehingga hasilnya lebih baik.

2. Bagi profesi

Penelitian lanjutan lebih ditingkatkan dengan beberapa persiapan diantaranya edukasi yang jelas dan praktis kepada responden, menyiasati lingkungan yang lebih terkontrol, penyusunan detektor kencing, sehingga hasilnya dapat lebih baik.

3. Bagi Masyarakat

Orangtua diharapkan lebih telaten membimbing anak dalam menjalani terapi, sehingga anak secara bertahap dapat sembuh dari kebiasaan ngompol.

\section{Daftar Pustaka}

Alwisol. 2009. Psikologi Kepribadian. Malang: UMM Press

Arikuto. S, 2002, Prosedur Penelitian, Suatu Pendekatan Praktis, Jakarta:PT. Rineka Cipta

Arikuto. S, 2006, Prosedur Penelitian, Suatu Pendekatan Praktis, Jakarta:PT. Rineka Cipta

Azwar, Saifuddin. 2009. Reliabilitas dan Validitas. Yogyakarta: Pustaka Pelajar

Boniecki, Kurt dan Stacy Moore. 2003. Breaking the Silence: Using a Token Economy to Reinforce Classroom Participation. Teaching Of Psychology, vol. 30, no. 3. http://apadiv2.org/ ebooks /tips2011/l-12- 03Boniecki2003.pdf. (28 april 2012)

Corey, Gerald. 2009. Teori dan Praktek Konseling dan Psikoterapi. Bandung: Refika Aditama

Dalton. Scot, 2000, Vegetative Disorder, Philadelphia:Nelson Tetbook of Pediatrics

Davidson, Gerald, dkk. 2010. Psikologi Abnormal. Jakarta: Rajawali Press

Direktorat Jenderal Pendidikan Anak Usia dini, Nonformal, dan Informal. 2012. Pedoman Pendidikan Karakter Pada Pendidikan Anak Usia Dini.

Edwards, Drew. 2006. Ketika anak sulit diatur: panduan bagi para orang tua untuk mengubah masalah perilaku anak. Bandung: Kaifa

Fahrudin, A. 2010,Panduan Terapi Psikososial Menggunakan Teknik Ekonomi Tokendi Panti Sosial. Bandung: Jurusan Rehabilitasi Sosial STKS Bandung.

Gunarsa, Singgih dan Yulia Singgih. 2008. Psikologi Perkembangan Anak dan Remaja. Jakarta: Gunung Mulia

Guyton \& Hall, 2007, Buku Saku Fisiologi Kedokteran, Jakarta:EGC

Harjaningrum, et. Al, 2007, Peranan Orang Tua dan Praktisi dalam Membantu Tumbuh Kembang Anak Berbakat Melalui Pemahaman Teori dan Tren Pendidikan, Jakarta:Prenada

Hidayat A Aziz Alimul. 2007. Metode Penelitian Keperawatan dan Teknik Analisis Data. Jakarta: Salemba Medika.

Kurniawati, Yuli. 2010. Modifikasi Perilaku Anak Usia Dini. Semarang: UNNES

Latipun. 2010. Psikologi eksperimen. Malang: UMM press

Miltenberger, R. G. (2001). Behavior Modification: Principles and Procedures. 
2nd ed.Belmont, California: Wadsworth/ Thomson Learning.

Notatmodjo, 2003, Ilmu Kesehatan Masyarakat, Jakarta:PT. Rineka Cipta

Notoatmojo, Soekidjo 2002, Metodologi Penelitian Kesehatan, Jakarta:Rineka Cipta.

Notoatmojo, Soekidjo 2005, Metodologi Penelitian Kesehatan, Jakarta:Rineka Cipta.

Notoatmojo, Soekidjo 2012, Metodologi Penelitian Kesehatan, Jakarta:Rineka Cipta.

Nursalam. 2003. Konsep dan Penerapan Metodologi Penelitian IImu Keperawatan. Jakarta: Salemba Medika.

Rahmat, Firlia. 2004. Token Ekonomi. http://lib.uin-malang. ac.id/ thesis/chapter ii/ 07620004-firlia-rachmat.ps (28 april 2012)

Rudolph. Alpers, 2006, Buku Ajar Keperawatan Pediatrik Rudolph. Edisi 20, Jakarta:EGC

Shrwood, 2001, Fisiologi Manusia dari Sel ke Sistem, Jakarta:EGC

Sloane. E, 2003, Keperawatan Medikal Medah:Sistem Perkemihan. Jakarta:EGC

Sujiono, Yuliani Nurani. 2005. Mencerdaskan Perilaku Anak Usia Dini Panduan Bagi Orang Tua Dalam Membina Perilaku Anak Usia Dini. Jakarta: Elex media komputindo

Sujiono, Yuliani Nurani. 2009. Konsep Dasar Pendidikan Anak Usia Dini. Jakarta: Indeks

Tanagho, E.A, 2008, General Urology, 15th ed, New York:Mc Graw Hill Companie

Tin Suharmini. 2002. Upaya Mengurangi Perilaku Hiperaktif Melalui Latihan Pengelolaan Perilaku. ( Laporan Penelitian ). Yogyakarta : FIP UNY

Tridjaya.B, (etc), 2005, Enuresis Nokturnal pada Anak, Jakarta:IDAI Jaya

Wantah, Maria J. 2005. Pengembangan Disiplin dan Pembentukan Moral Pada Anak Usia Dini. Jakarta: Depdiknas.

Zainah.2004. Reward and punishment. (http://lib.uin-malang.ac.id/thesis/ chapter ii/07110178-sy-zainah.ps) (28 april 2012) 